The Dovey Salt Marshes in 1921

Author(s): R. H. Yapp

Source: Journal of Ecology, Vol. 10, No. 1 (May, 1922), pp. 18-23

Published by: British Ecological Society

Stable URL: http://www.jstor.org/stable/2255428

Accessed: 27-06-2016 09:48 UTC

Your use of the JSTOR archive indicates your acceptance of the Terms \& Conditions of Use, available at

http://about.jstor.org/terms

JSTOR is a not-for-profit service that helps scholars, researchers, and students discover, use, and build upon a wide range of content in a trusted digital archive. We use information technology and tools to increase productivity and facilitate new forms of scholarship. For more information about JSTOR, please contact support@jstor.org.

Wiley, British Ecological Society are collaborating with JSTOR to digitize, preserve and extend access to Journal of Ecology 


\title{
THE DOVEY SALT MARSHES IN 1921
}

\author{
By R. H. YAPP. \\ (With three Figures in the Text.)
}

In a previous paper the building and subsequent modification of a salt marsh were described ${ }^{1}$. As the work was carried out during a comparatively short time, the changes in surface relief were studied mainly by the indirect method of comparison of different stages. This method yielded adequate information regarding the sequence of events, but afforded little indication of the rate at which the various progressive and retrogressive changes proceed. A few notes on changes observed after the lapse of seven years may supplement the earlier account ${ }^{2}$.

\section{Rate of Erosion of Pans.}

Fig. 1 shows a system of "pans" on Armerietum surveyed in 1914 and again in $1921^{3}$. In 1914 active erosion appeared to be in progress, and it was evident that sooner or later the pans would coalesce to form a "compound pan" (Y. J. p. 90). The following measurements indicate the rate at which erosion has proceeded since 1914.

Width of narrowest part of neck separating:

\begin{tabular}{|c|c|c|c|c|c|c|}
\hline & $\begin{array}{c}\text { Aug. } 20 \text {, } \\
1914 \\
\text { inches }\end{array}$ & $\begin{array}{l}\text { Jan. 8, } \\
1916 \\
\text { inches }\end{array}$ & $\begin{array}{l}\text { Oct. 3, } \\
1916 \\
\text { inches }\end{array}$ & $\begin{array}{c}\text { May } 21, \\
1921 \\
\text { inches }\end{array}$ & $\begin{array}{c}\text { Aug. } 30, \\
1921 \\
\text { inches }\end{array}$ & $\begin{array}{l}\text { Average decrease } \\
\text { per annum } \\
\text { inch }\end{array}$ \\
\hline $\mathbf{A}$ and $\mathbf{B}$ & $12 \cdot 0$ & $10 \cdot 0$ & $9 \cdot 0$ & $9 \cdot 0$ & 8.5 & .5 \\
\hline C, $\mathbf{D}$ & $5 \cdot 0$ & $4 \cdot 5$ & $3 \cdot 5$ & \multicolumn{2}{|c|}{ cut through } & $1 \cdot 0 ?$ \\
\hline $\mathbf{C}, \mathbf{F}$ & $12 \cdot 5$ & $12 \cdot 0$ & $12 \cdot 0$ & $12 \cdot 0$ & $12 \cdot 0$ & .07 \\
\hline $\mathbf{E}, \mathbf{G}$ & $12 \cdot 0$ & - & $11 \cdot 0$ & $10 \cdot 5$ & $9 \cdot 75$ & .32 \\
\hline
\end{tabular}

Seeing that in these cases both sides of the neck of land are exposed to erosion, it is obvious that the "pot hole" action by which individual pans enlarge and tend to become circular (Y.J.p. 89) is a very slow process, even on somewhat sandy marsh ${ }^{4}$. At this rate it may be another 30 to 50 years before this particular pan system becomes a fully developed compound pan.

1 Yapp and Johns. "The Salt Marshes of the Dovey Estuary, Part II." This JournaL, 5, 1917. This paper will be referred to in the text as (Y. J.).

2 The earlier work was carried out during 1913-14. Subsequently, Mr Johns paid two visits to the marshes in 1916, while I saw them in May and August of 1921. I am indebted to Miss Slane, Dr Elliott, and other members of the Birmingham University Botanical Department for assistance in re-surveying during the May visit.

3 This system is shown in Y. J. Fig. 9, p. 88, and Pl. XVI, Phot. 19.

4 For mechanical analyses of this soil see Armerietum, Y. J. p. 67. 
The necks of land were selected for measurement on account of ease of identification, but it does not follow that all parts of a pan erode at a similar rate. In a sheltered estuary tidal scour is apparently more effective than wave action as an agent of denudation, and in the case of pans the chief work is done during comparatively few seconds as the tide sweeps into the pan. Different parts of a pan may therefore erode at different rates according to the point from which the tide enters the pan. Further, projecting portions tend to erode comparatively rapidly, as for instance when a neck of land separating two pans has been breached. Thus the successive widths of the opening connecting pans $\mathbf{B}$ and $\mathbf{D}$ (Fig. 1) on the dates given in above table

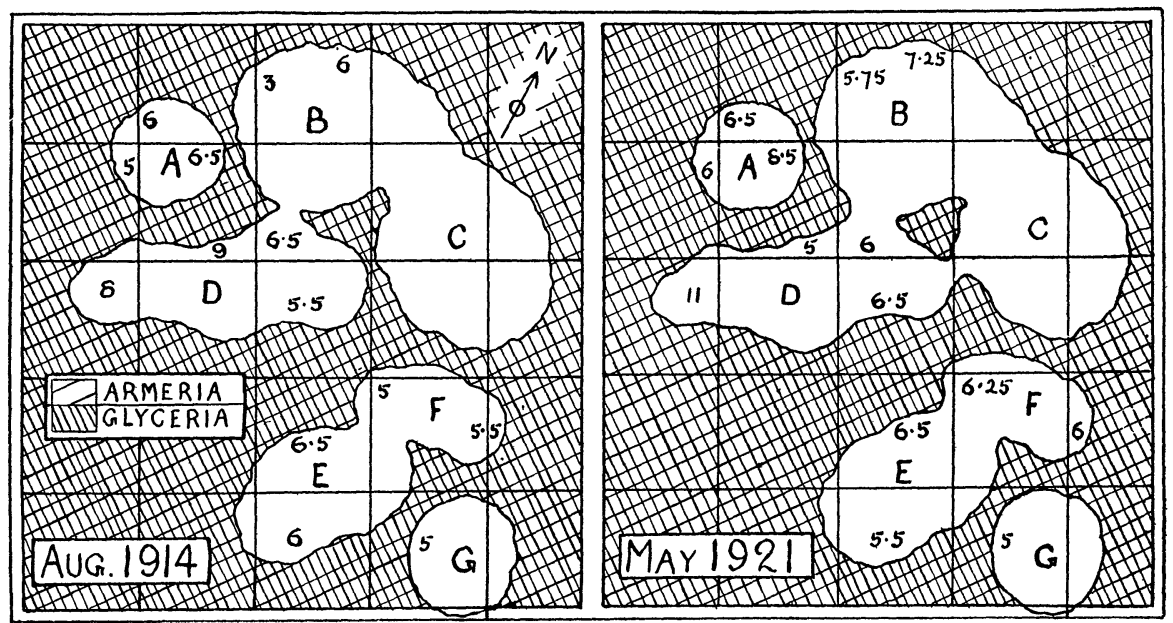

FIG. 1. System of pans on Armerietum (sandy marsh) in process of erosion. Figures refer to depths of pans. Small squares five feet each way.

were: 8, 13, 14, 24, 24 inches. Again, the opening between $\mathbf{C}$ and $\mathbf{D}$, breached about 1919 (?) was already 13.5 inches wide on May 21, 1921, and $15 \cdot 5$ inches on Aug. 30, 1921.

Along the river side of the "saltings" the soil is more sandy (cf. analyses, Y. J. p. 67) and tidal scour greater. Here it was apparent (though no exact data are yet available) that both erosion and the formation of secondary marsh proceed more rapidly than changes on the surface of old established marsh.

The slow rate of erosion of undrained pans has some bearing on the question of whether pans can originate on old marsh in consequence of destruction of the vegetation. Warming ${ }^{1}$ thought that pans may form where turf has been weakened or destroyed by putrefying masses of algae or Zostera, the weak

1 Warming. "Bidrag til Vadernes, Sandenes og Marskens Na.turhistorie." Mém. Acad. Roy Sci. et Lettres de Danemark, Copenhague, 7me sér., Sect. d. Sci. 2, 1904. 
spots being subsequently excavated by the sea. We (Y. J. p. 87) could find no evidence that in the Dovey Estuary pans originated in this way. Subsequently Harrison ${ }^{1}$ has expressed the opinion that Warming's view is tenable. He says (p. 124) that piles of Fuci bury small hollows six inches deep in decaying algae and other rubbish. "Here, directly on the Statice, primary pans are immediately inaugurated when the vegetation beneath dies off." This statement is unconvincing, and it is unfortunate that Harrison does not adduce more evidence in support of his view. We mentioned (Y. J. p. 87) an experiment in which a circular piece of Armerietum turf was removed, thus giving wave and tidal action every chance of enlarging the small artificial pan so formed. After seven years this pan has still the same diameter (18 inches) as when first made. This fact, together with the slow rate of enlargement of natural pans, and the very great binding power of the matted roots, make it difficult to believe that wave action could remove the turf and bring about mobility of the substratum "immediately" on the death of the vegetation. Of course, as we pointed out earlier (Y.J. p. 87) "in some estuaries wave action may be more potent than in the Dovey," and methods of pan formation other than those noticed on the Dovey marshes may obtain elsewhere. Convincing evidence, however, for this particular method appears to be lacking. Prof. F. W. Oliver too, informs me that in view of Warming's statement, he watched some cases of this nature at Erquy, "but pans failed to materialize."

\section{Colonisation of Drained Pans.}

Effective drainage of pans leads to invasion by vegetation, Glyceria being in most cases (on the Dovey) the first colonist (Y. J. pp. 93-4). In 1914 a number of pans were artificially drained, and by 1916 Glyceria had commenced to invade the majority of these. By 1921 colonisation had progressed much further, but in the cases examined the vegetation was still in the Glycerietum phase, though a few young plants of Armeria etc., were sometimes present. Fig. 2 shows the degree of invasion of a large compound pan which, when artificially drained in 1914, was completely bare of vegetation ${ }^{2}$. Wadham observed the same phenomenon on the Holme marshes ${ }^{3}$.

It was recorded previously (Y.J. p. 96) that colonisation of high level pans (e.g. in Festucetum); which rarely have definite drainage outlets, appeared to be a slow and difficult process. The Talsarnau salt marsh (near Harlech, $\mathrm{N}$. Wales) affords a contrast in this respect. On this marsh a large number

1 Harrison. "A Survey of the Lower Tees Marshes and of the Reclaimed Areas adjoining them." Trans. Nat. Hist. Soc. of Northumberland, Durham, and Newcastle-upon-Tyne, N.S.5, 1918.

2 A photograph of this pan (looking eastwards), as it appeared in 1914, is given in Y. J. Pl. XVI, Phot. 20.

${ }^{3}$ Wadham. "Changes in the Salt Marsh and Sand Dunes of Holme-next-the-Sea." This Journal, 8, 1921, Figs. 3 and 4. 


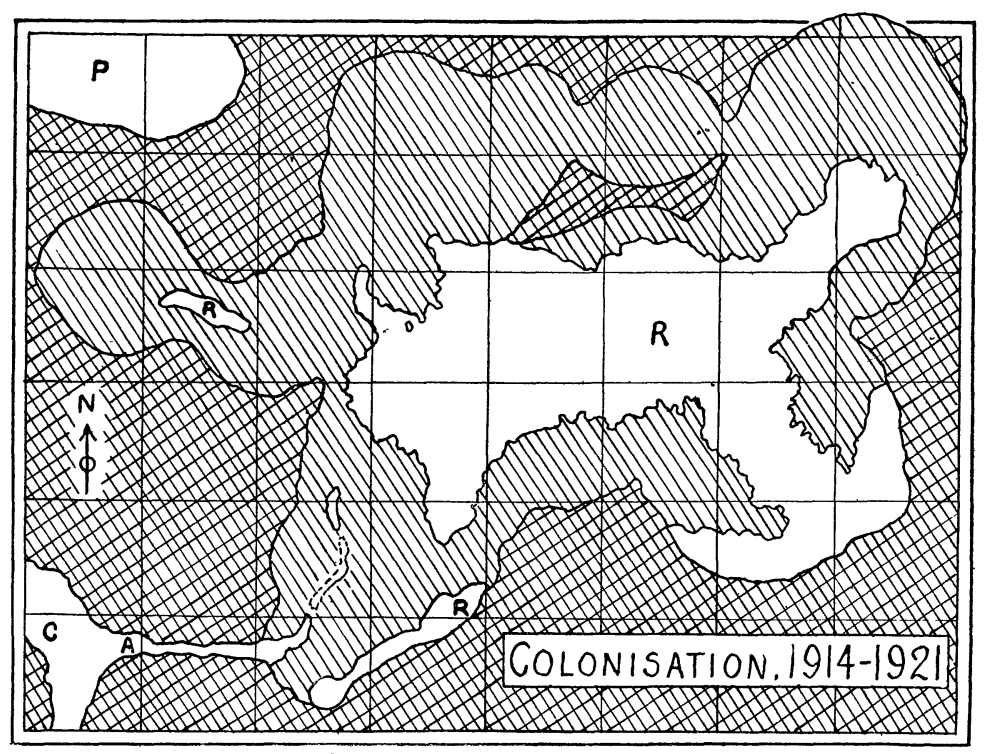

Frg. 2. Large compound pan (40 feet long) showing colonisation due to drainage. A, artificial drainage cut leading into channel $\mathbf{C}$. $\mathbf{R}$, incipient residual pans. $\mathbf{P}$, ordinary undrained pan. Squares five feet each way.

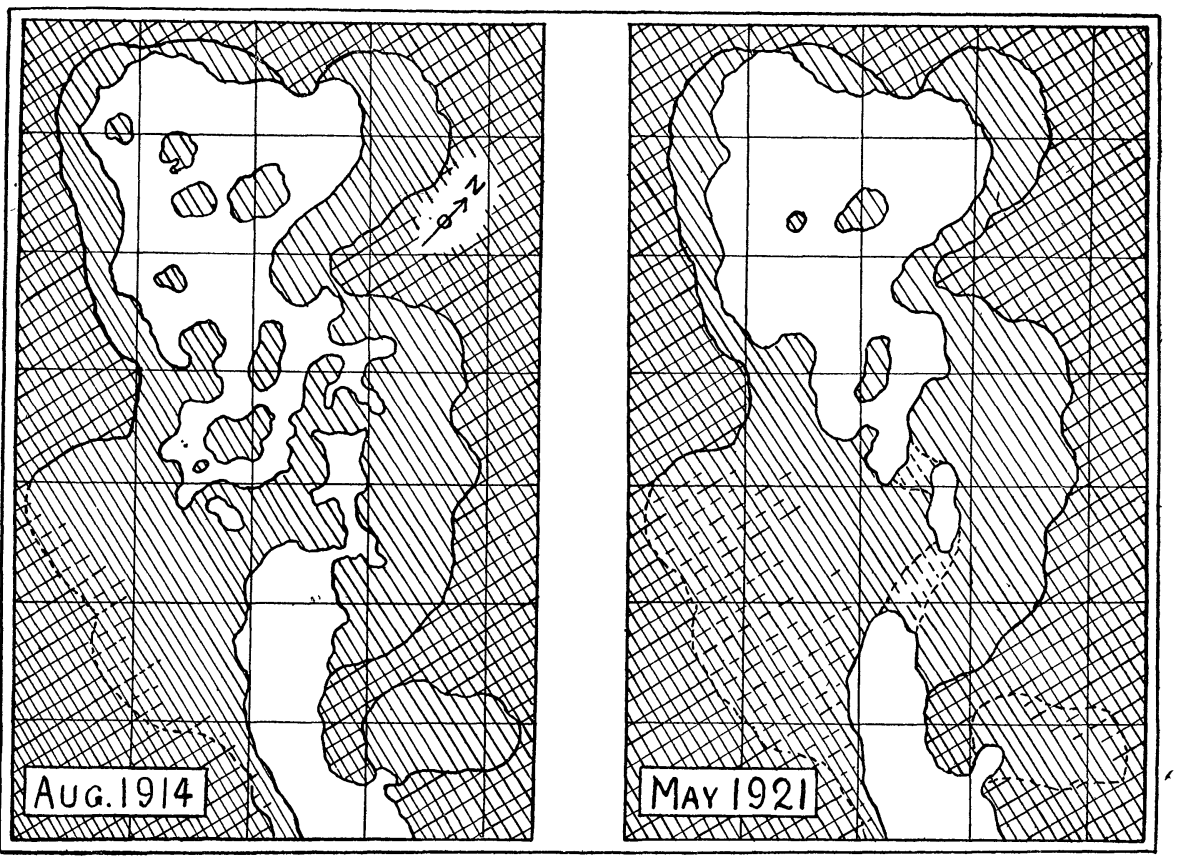

Fig. 3. Compound pan showing stages in the development of a residual pan. Armeria is invading the Glycerietum. Squares five feet each way. 
of high level pans, though devoid of drainage outlets, were (in 1920) completely carpeted with vegetation ${ }^{1}$. This is probably to be correlated with the fact that the Talsarnau marsh is a particularly sandy one, drainage by percolation being sufficiently rapid to permit the growth of vegetation.

Residual Pans. These-are formed from bare patches cut off by the growth of vegetation during the colonisation of drained pans (Y. J. p. 87; cf. also Wadham, l.c. Fig. 4). Several of the pans drained in 1914 show incipient residual pans (e.g. Fig. 2). Fig. 3 (1914) shows an old compound pan in which such an incipient residual pan had been formed by the secondary blocking of the outlet by Glyceria. At that time the Glyceria was but little higher than the bare portion, and it appeared probable rather than certain that a definite residual pan would result. The 1921 survey shows the subsequent changes. Several Glyceria islands have disappeared, the remaining ones, as well as the sides of the pan, having been raised by the accretion of silt well above the floor level. The history of this now well-established pan shows that the residual pan may be regarded as a definite type.

Economic aspect. The compound pan shown in Fig. 2 has an area of about 594 square feet. Of this about two-thirds (387 square feet) has been carpeted by vegetation in seven years, in spite of the secondary blocking of the outlet. Comparable results have been seen in other cases. It seems clear that a very substantial addition could be made to the available sheep pasturage, by systematically connecting up the pans and draining them into channels at a lower level. If the outlets were kept open, so as to prevent the formation of residual pans, a sward, more or less continuous except for the channels themselves, would be produced. From the farmer's point of view, this method of surface drainage, by which use is made of existing channels, is, I think, the most effective and economical method of draining an old established salt marsh.

\section{SPARTINA TOWNSENDII.}

On August 29, 1921, this plant was found on the Dovey marshes. It is certainly a recent arrival, and has every appearance of having spread to the Dovey by natural means. So far as I am aware, this is the first record of the natural occurrence of Spartina Townsendii in Britain, except on the south coast where it has spread so rapidly since its appearance in $1870^{2}$. It has, however, been transplanted to several localities, the nearest to the Dovey being Clevedon in Somersetshire ${ }^{\mathbf{3}}$, whence it may have spread northwards. Its advent in the Dovey is of considerable interest, as it may bring about

1 Chiefly Glyceria, but usually mixed with Triglochin and Glaux (cf. Y. J. p. 96). Some pans showed Glaux in the centre, surrounded by a slightly higher zone of Glyceria.

2 Stapf. "Townsend's Grass or.Rice Grass." Proc. Bournemouth Nat. Sci. Soc. 5, 1913. Also Oliver. "Spartina Problems." Ann. Appl. Biol. 7, 1920.

${ }^{3}$ Oliver, loc. cit. p. 35. Clevedon is something like 200 miles by sea from the Dovey. 
far-reaching changes in the estuary. It is hoped to watch its future progress; in the meantime its first occurrence may be recorded.

In all ten clumps of Spartina were found, scattered over about threequarters of a mile on the south side of the Dovey, and some five miles from the open sea ${ }^{1}$. All were growing in wet mud, and appeared to be well established. Several of the clumps were a foot or more in diameter, the largest being about 16 inches; four of the clumps were in flower.

1 Two clumps (12-15 inches diameter; both in flower) on a raised spit of mud in a channel just west of large breakwater B (Y. J. Fig. 1, p. 66). Four more clumps (6-16 inches diameter; two in flower) between $B$ and $C$. The remaining four clumps were small and spread out further to east. All the clumps except the two furthest to east were close to the saltings, one on bare mud actually enclosed by Glyceria. 